\title{
Original Documents
}

\section{A. W.}

To cite this article: A. W. (1847) Original Documents, Archaeological Journal, 4:1, 341-354, DOI: 10.1080/00665983.1847.10850668

To link to this article: http://dx.doi.org/10.1080/00665983.1847.10850668

册 Published online: 06 Dec 2014.

Submit your article to this journal 중

Q View related articles $₫$ 


\section{Qriginal 7 ocuments.}

\section{SURVEY OF THE TOWER ARMORY IN THE YEAR 1660.}

'I'He inventory here offered to our readers as a valuable illustration of military costume, is already partially known through a transcript communicated to the Society of Antiquaries by Mr. Bray, in 1792. It was published first in the eleventh volume of the Archæologia, and reprinted by Sir Samuel Meyrick, in his Critical Enquiry ${ }^{\text {a }}$. The attested copy, in the possession of the late Mrs. 'Tucker, of Betchworth Castle, Surrey, was the authority whence the text of this interesting document was thus derived, the existence of the original being hitherto unknown. It had, however, been preserved amongst the Records in the Audit Office, and we are indebted to Mr. Cunningham for bringing it to light from a neglected mass of old evidences, and for the communication of an accurate transcript.

'This original bears the autograph signatures of the Lieutenant of the 'Tower and of the Commissioners, appointed by Charles II. on his restoration to survey the armour and munitions remaining in his armories. A collation with the printed text has shewn various errors and omissions in the copy, as published by Mr. Bray, amongst which may be mentioned the particular description of nine suits of armour, with other curious items, not found in his communication given in the Archæologia. It has been thought, therefore, that an accurate copy of the entire document, hitherto only imperfectly known through the costly publications above cited, cannot fail to be acceptable to many readers of the Archæological Journal.

The following survey appears to be the earliest inventory extant of any extensive assemblage of armour in the royal arsenal at the Tower of London. Various evidences have been preserved relating to military stores preserved in that fortress,

VOL. IV.

a Crit. Enqu., vol. iii. p. 106, edit. 1834.

Y $\mathrm{y}$ 
or thence supplied at various times, from an early period; and some account of these is given by Mr. Hewitt, in his useful hand-book, which we have taken occasion elsewhere to commend to the notice of our readers". Amongst these records may be cited particularly the "Inventory of Ordenaunce, munition and other goods, belonging to our late soverayne Lorde, King Henry VIII.," as examined by commissioners appointed by Edward VI. on his accession, in 1547. The original MS., formerly in the possession of Gustavus Brander, is now in the library of the Society of Antiquaries ${ }^{c}$, and the entries relating to the Tower are given, with the munitions of various fortresses, in Sir Samuel Meyrick's Critical Enquiry ${ }^{d}$. None of the suits, however, described in the following survey, as having belonged to sovereigns and great personages, are mentioned in that document; the only armour named as then existing in the Tower being brigandines, variously arrayed, and defences known as "millars' coats."

It has not been satisfactorily ascertained at what period, or by whose direction, any collection of remarkable armours and weapons was formed at the Tower, or became a military display, similar to those armories in foreign parts, which already began to claim the notice of the curious, in the sixteenth century. Sir Samuel Meyrick is disposed to associate the name of Henry VIII. with those of Maximilian, Charles V., and Francis I., as the sovereigns to whom the foundation of the armories of Europe is to be attributede. Positive evidence does not appear to have been adduced, but it may readily be supposed that either at Windsor, or in the Green Gallery at Greenwich, the favourite scene of the splendid festivities of Henry's reign, some display of martial equipments might have been commenced ${ }^{f}$. One of the earliest armories of note in Germany appears to have been that formed by the archduke Ferdinand II., at the castle of Ambras, near Inspruck, during the reign of Elizabeth, about 1560 . The invitations personally addressed on that occasion by the archduke to the princes and distinguished military characters of the age, requesting them to contribute suits which they had worn, would naturally

- The Tower, its History. \&c. See the Notices of Archæological Publications.

c Manuscripts, No. 129.

¿Vol. iii. p. 11.

e Critical Enquiry, vol. iii. p. 105.

f In the Privy Purse Expenses of Henry
VIII., 1529-32, considerable payments appear to Erasmus, Asmus, or Asamus, "the King's Armerer," Thomas Wolverd, armerer, "to him that kepith the Armery in Wyndesour," \&c. 
stimulate in Europe a taste for establishing similar collections. 'That some such assemblage of armour of more than ordinary importance had been formed, during the times of Elizabeth, is sufficiently shewn by the account so often cited which Paul Hentzner gave of his visit to the Tower in 1598. The full import of his relation, however, does not appear to have been admitted; his attention was chiefly attracted by the striking suit which had belonged to Henry VIII., but it is clear from the Latin original that various other remarkable armours for man and horse were then in the "armamentarium" at the Towerg. The phrase "arma multa et egregia, tam pro viris, quam pro equis, in equestri pugna," ambiguously rendered "many and very beautiful arms," in the English translation, may suffice to prove that some of the suits of armour, cap-a-pie, with horse furniture of the same, enumerated in the following survey, formed, as early as the forty-first year of Elizabeth's reign, part of the display in the Tower armory, augmented in the following century by some from the Green Gallery at Greenwich, as we learn from this document of $1660^{\text {th}}$. The curious, fact recorded by Stowe that a lottery for rich and curious armour was opened in St. Paul's churchyard in 1588 (29 Eliz.), being probably the spoil of the Armada, may not be undeserving of notice, as appearing to indicate a more general estimation of such objects than might have been expected in peaceful times, and under the decline of the popular taste for tournaments and chivalrous display.

The original inventory here printed forms a thin folio volume, endorsed thus on the parchment cover: "The Booke of Remayne of the Office of the Armory, in the Charge of William Legge, Esqur. taken in the month of October, Anno R. R. Caroli secundi 12, Annoque Domini, 1660"."

g Pauli Hentzneri Itinerarium, Norib. 1629 , p. 192. In the "Estimate of Remaines in the Office of Ordinance," 1578 , 20 Eliz., twenty years previous to Hentzner's visit, a return is made of rich weapons in the Tower, estimated at $£ 2300$, but no mention occurs of suits of armour. Annual Expenses of Elizabeth, printed in Household Ordinances, published by Antiqu. Soc., p. 272.

$h$ 'The title of "Queen Elizabeth's Armory," which now designates only the collection formerly preserved in "the
Spanish Weapon House," dates only from the arrangement of the whole by $\mathrm{Sir}$ Samuel Meyrick, in $\mathbf{1 8 2 5}$. We must leave the question to the intelligent investigation of Mr. Hewitt, whether this title might not with propriety be assigned to the entire National Collection, and the earliest formation of such a display be attributed to the reign of Elizabeth.

i The contracted words have been printed in extenso, and common figures used in place of Roman numerals, employed in the MS. 


\section{THE OFFICE OF THE KINGES MAJESTY'S ARMORYE.}

A VIEw and Survey of all the Armor, and other Municion or Habiliaments of Warr, remayneing at the Tower of London, Taken in the month of October, 1660, By vertue of a Commission under the signe Manuall and privy signet of his most excellent Majestie, Charles the second, by the Grace of God, of England, Scotland, France and Ireland, King, etc.: directed unto Sir John Robinson, Knight, Leiften'nt of the Tower of Lnndon, Collonell William Ashburneham, Sir Thomas Armestronge, Knight, John Wood and Bartholmew Beale, Auditors of the Imprests. The Teanor of which said Commission hereafter ensueth, in theis wordes, vizt. Charles Rex, Trusty and welbeloved, Wee greet you well. Whereas our welbeloved Servant, William Legg, esq ${ }^{\mathrm{T}}$., Master of our Armoryes, in the Tower of London, Greenwich and elsewhere in our Kingdome of England, hath byn by the late unhappy differences in this our Kingdome outed of his said Office, and the same put into the hands of other unknowne persons: Our will and pleasure is, that he enter upon, and take the Execucion of the said office into his hands, as formerly. And upon his humble request that a Survey of the same may be taken, to the end it may be knowne unto us, what Armes are remaineing in our said Armoryes, that he may be duely Charged with them to make Accompt to us; Wee, haveing made choyce of you out of our trust and confidence in you, doe hereby authorize, appointe, will and require you all, or any two of you, one of the Auditors of our Imprests being one, to take the Remaines of all our Armes, Tooles and other Utensils, in our Tower of London, and Magazines and Storehouses at Greenwich. And wee doe authorize and require you for our good service herein, imediately without delay to repaire to the said places, and there to call before you for your better assistance herein, John Loup, Clerke of our Armoryes, Richard King and Thomas Cox, two of our Armorers, that all you may joyntly together proceed to the Execucion of this our will and pleasure for the good of our service: And alsoe to call before you the present officer, Officers, Storekeeper and all others whom you shalbe informed of, that now hare, or have, at any time, had the keepeing or Surveying of our said Armoryes, And that in your Bookes to be made thereof you doe perfectly distinguish what quantityes of every nature, then and there found remayneing, are good and serviceable, what defective and what unserviceable, to the end we may bee truly informed of the state of that our office: And, if you find any to be imbezelled, to Certifie the same alsoe, and by whom. Given at our Court at Whitehall, this second day of August, in the Twelfe yeare of our Reigne. By his Majesties Comaund. Edw. Nicholas. To our trusty and welbeloved Sir John Robinson, Leiften'nt of our Tower of London, Collonell William Ashburneham, Sir Thomas Armestrong, knt. John Wood, Bartholmew Beale, Auditors of the Imprest.

Accordinge to the purport and direction of which said Comission, the said Comissioners or two of them, whereof one of the said Auditors was con- 
stantly one, have meett and proceeded in the said service, and have taken the whole Remayne of all the Armors, Municion and other Habiliments of Warre, with their Furnitures, in the said Tower of London (sundry of the Armours, with their Furnitures and other utensills, which were formerly at Greenwich, being (within the tyme of the late distraccions and unhappy differences in this Kingdome) removed unto the said Tower of London) all which they find to be of the severall natures and qualityes hereafter menconed : viz. :

ARMORS AND OTHER FURNITURES, VIZ. AT THE TOWER OF LONDON.

Harquebuzeers with other Horsemens Armors, vizt.

Breasts, Serviceable, 6604. To be repaired, 2394. Unserviceable, 5

Backes, Serviceable, 5859. To be repaired, 3416. Unserviceable, 6

Headpeeces, Serviceable, 5584. To be repaired, $2826 \quad .8410$

Strong Harquebuze armor, consisting of backe, breast, Placket, headpeece and Taces . . . . One

Strong Breast and Placket . . . . One

Dutch horsemens headpeeces, with single barrs . $\quad 776$

Dutch Harquebuze armes defective, Breasts, 132. Backes . 100

Curasseers Armors, with their Furnitures, viz.

Close white Curasseer headpeeces, defective . . . 228

Curasseer armes compleate, whereof 43 defective $\quad 58$

Cushes, to be cleaned and repaired . . . 289 paire

Kneecopps. To be cleaned and repaired, 252 paire. White and cleane, 17 paire

Flemish Pouldrons, with Vambraces, to be repaired

Light Horsemens armes, white, wanting two paire of Taces .

White Curasseer armes compleat, for Tilting . .

Tilting armor for Curasseers, consisting of backe, breast, Pouldrons, Vambraces, Taces and Collar . . One

Large white Armour cap-a-pe, said to be John of Gauntsk . One Small white Armour cap-a-pe, said to be Prince Henryes . One

Corslets and Curats with their Furnitures, viz.

Danish Foot armes, to be repaired, viz. Breasts, 344, Backes, 255, Breasts with Taces, 42.

Danish breasts with crosse Girdles, to be cleaned and repaired 1009

Armour of Toyras provision, riz. Breasts, whereof to be repaired, 229-291; Backes, whereof to be repaired, 236298. Headpeeces, whereof made in England, to weare with the said Armes, and to be repaired, 227 .

Grose, plate xxii. 
Curate breasts, viz. unserviceable, 1066, and to be repaired,

Curate backes, viz. unserviceable, 934 , and to be repaired, 220. In all

Headpeeces

Taces and old breasts, unserviceable .

Coome Murrions, and other old headpeeces and Capps, unserviceable

Gorgetts, to be cleaned and repaired .

Murrions used on shipboard, unserviceable

Spanish Murrions, unserviceable

White feild headpeeces, defective

Masking Armour compleat, reported to be made for King Henry the vijth.

One

Foote armes compleat, and serviceable, viz. Black and plaine, 5. Blacke and guilt, $3 \quad$. $\quad$. $\quad$.

Sundry parcells of Tilt Armour, defective, viz.

Headpeeces, wanting 4 Collers

Breasts, viz, with short Taces 4, without Taces, 2

Backes

Pace-guards, viz. Russet, 7. White, 3

Gran guards, viz. Russet, 7. White, 2

Pouldrons

Vambraces, viz. Plaine, 2 paire, Guilt, 2 paire

Knee-copps

Oldgrave

Culet, or Guardreine

4 paire

1 paire

Headpeeces

Taces .

Mainefaires, viz. Russet, 4, White, 2

One

One

2

3

6

Vampletts for tilting staves

White short Gauntletts

White tilt Collars

Sundry other Armes and parcells of Armour, Municion \&c. viz.

Flemish Gauntlets, unserviceable, viz. Short, 474, Long, 10484

Amunicion swords, to be cleaned and scabberded . 245

Belts for swords . . . . . . 40

Sadles for great horses, without any manner of Furniture, to be repaired

Severall old peeces of steele Plates for great sadles, unserviceable, whereof ten have byn damasked and guilt . 31

Severall old peeces of Armour, of sundry sorts . . 20

Batle Axes 
Wood Crosses to hang Armour upon, whereof 30 are to be repaired

Shaffrones, viz. To be repaired, 92, White and serviceable, 42

Lances and Lancestaves, unserviceable

Great Lances, whereof two are said to be King Henry the

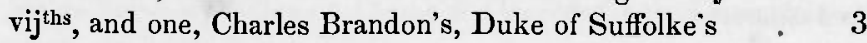

Pikes, unserviceable . . . . 11

Great Hearce of John of Gaunt's . . . One

Spanish Coller for torture, taken in $88^{t} .{ }^{l}$. . One

Two Hand swords . . . . 2

Sheilds guilt . . . 2

Targetts of Iron - . $\quad$. $\quad . \quad 26$

Bucklers of Iron . . . . . . 2

Wooden Bucklers . . . . 2

Barbes for horses, wanting one shaffron . . 2

Anticke Headpeece with Ramshornes, Coller, and spectacles upon it, one Jacke $\mathbf{m}$, and one sword, all said to be William

Sommers' armes

. One

Armorers Tooles, viz.

Small Bickernes . $\quad$. $\quad$. $\quad$. $\quad$. 6

Tramping stakes . $\quad . \quad$. $\quad .6$

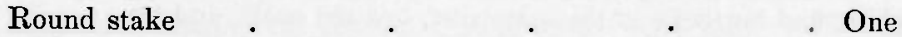

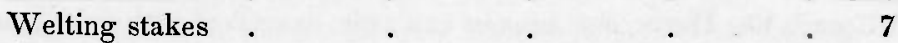

Strait Sheeres . $\quad$. $\quad$. $\quad$. $\quad . \quad 2$ paire

Fileing Tongues . $\quad . \quad$. $\quad . \quad$. 1 paire

Hammers

Old tew Iron

Great square Anvill

Anvill, broke

Old Bellowes, whereof one paire said to be $\mathbf{M}^{\mathrm{r}}$. Anneslyes

Smiths vices

2

One

One

One

Threstles

In the Closet within the Armory at the Tower.

Armour of King Henry the $8^{t_{5}}$. cap-a-pe, being rough from the hammer

- One

Long Elbow Gantletts $\quad . \quad$. $\quad$. $\quad$. $\quad$. 273

Strong brests and Placketts $\quad$. $\quad$. 2

Harquebuze armes, viz. Backes, 30, Breasts, whereof 3 defective, 16

Round Cap, unserviceable .

. One

1 This signifies the year 1588, the date of the Spanish invasion.

m Erroneously printed "tacke," in the
Archæologia. This jack appears to have been in existence within memory of persons now employed in the armories. 
Culet

Old mainefares .

Pouldrons

Footemans breast

Old sword

Sword belts

Male Jacketts

Powder

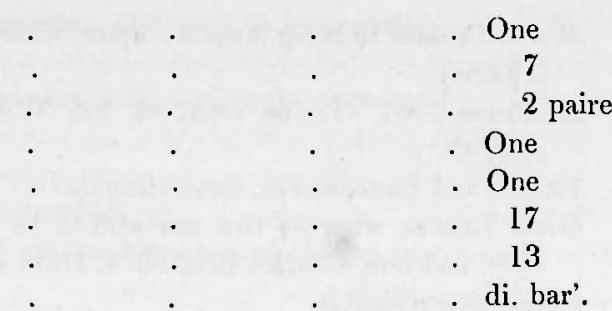

Old peeces of Armour of severall sorts, unserriceable, whereof some of them have byn parcell guilt

In the Hall of the Leiftenn't of the Tower.

Harquebuze armes compleat

Curasseer armes compleat . . One

Sundry compleat Armours and others, whereof some of them were standing formerly at Greenwich, in the greene Gallery there, viz.

(2. ${ }^{\mathrm{n}}$ Upon a horse statue of Wood, one compleat Tilt Armour, cap-a-pe, richly guilt, part engraven, part damasked, made for Prince Henry, with two Gantlets and one guilt grandguard. The horse Furniture being one Shaffrone of the same sort, one old leather sadle, and bit.

(5.) Upon a like Horse, one Armour cap-a-pe, white and guilt, made for King Henry the viij th. The horse Furniture being one shaffrone, brest plate, and buttocke of the same sort, one old sadle, and bit.

(6.) Upon a like Horse, one Armour cap-a-pe, damasked with gold, made for King Henry the vijth. The horse Furniture being a shaffrone, $\mathrm{Crinet}^{\circ}$ for the necke, brest plate, and buttocke of the same, sadle, stirrups, and bit.

(9.) Upon a like Horse, one Armour cap-a-pe, white, engraven and parcell guilt, made for King Edward the third. The horse Furniture being one shaffrone, Crinet for the necke, brest plate, and buttocke of the same, an old sadle, and bit.

(1.) Upon a like Horse, one Curasseer Armour richly guilt and Engraven, made for his late Majestie, of ever blessed memorye, Charles the first. The horse Furniture being one shaffrone of the same, and an old sadle.

(8.) Upon a like Horse, one white Armour cap-a-pe, made for King Edward the iijth. The horse Furniture one shaffrone, Crinet for the Necke, brest plate, buttocke, and one old sadle, with two Gantletts and a pace guard.

a These numbers, probably by a second hand, are written on the margin of the MS. and may possibly serve to indicate some old arrangement of these suits.

- Printed "Crivet" in the Archæologia, by the error of the transcriber, who read the $\mathrm{n}$ as $\mathrm{u}$, (for v.) Hall in his Chronicles uses the term cranet or crane, synonymous with crinet. "Criniere, a crannet, armour for the neck, or mane, of a horse." Cotgrave. 
(7.) Upon a like Horse, one Armour made for Kinge Henry the $\mathrm{vj}^{\text {th }}$., consisting of an headpeece, backe, breast, a paire of Pouldrons and Vambraces, a paire of Greaves, and a pace guard. The horse Furniture being a shaffrone, and an old sadle, and a bit.

(3.) Upon a like Horse, one Armour compleate, cap-a-pe, engraven with the ragged staffe, made for the Earle of Leicester. The Horse Furniture being a shaffroner, Crinet for the Necke, and brest plate of the same, one sadle, bit, and Reynes.

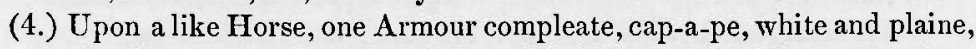
made for Charles Brandon, duke of Suffolke. The Horse Furniture being a shaffron, brest plate, and buttocke of the same, one sadle, bit, and bridle.

(10.) Upon a like Horse one Armour compleat, cap-a-pe, white and plaine, made for William the Conqueror, the Horse Furniture being a shaffron, Crinet for the Necke, with a sadle, bridle, and stirrups.

Sundry rich Armours, and parcells of Armor, brought from Mr. Anneslyes house, and now remaineing in severall Trunckes, within the office of the Armory at the Tower, (with 2 great Trunckes and one great Lead cisterne still at the said house,) viz.q

Armour cap-a-pe, richly guilt and graven, made for his late Majestie, of blessed memory, Charles the First, with Gantletts, and a shaffron of the same, and guilt steeles for a sadle. One

Small Armour, made for his now Majestie, Charles the second, when he was Prince, consisting of Breast, backe, gorgett, and headpeece, all richly guilt

. One

Curasseer Armour, richly guilt, made for his aforesaid late Majestie, Charles the first, when he was young, consisting of a backe, brest, headpeece, Gorget, Pouldrons, and Vambraces, Culet, Cushes, and Gantlets .

. One

Small Armour for horse and Foote, richly guilt, with bosses of gold, and corded with silver, consisting of backe, breast, taces, Murrion, close headpeece, Pouldrons, and Vambraces, with gorget and Gantlets

. One

Foote Armour of Henry the viijth., richly guilt, consisting of backe, brest, and placket, Taces, Gorget, a Burgonet with a buffe or chin peece

. One

Small Horse Armour compleat, cap-a-pe, richly guilt and chaced, with gantletts

Stirrups richly guilt and chaced

Sleeves of Male, with a velret Coate to them

. One

. 1 paire

.1 paire

1" This piece is figured by Grose, pl. 24.

4 The description of the following suits, with the exception of that of Henry VIII. is omitted in Mr. Bray's paper in the Archæologia, and in the Critical Enquiry. 
Small Tilt Armour capape, richly guilt and chaced, wanting onely Gantletts and Mainefare, with a shaffron of the same One

Small Armour, richly guilt and chaced, consisting of backe, brest, Culet, Taces, Gorget, Poiseguard, Mainefaire, and Gantletts . One Tilt headpeece of the late Prince Henryes, guilt and graven . One Vamplets for Tilting staves, guilt and graven . $\quad$. 6 Armour richly guilt and graven, consisting of a backe, breast, Cushes, a paire of Kneecops, Gorget, a paire of short Taces, one Burgonett with a Buffe, Murrion, one Gantlet, and a shaffrone, with a paire of guilt steeles for a sadle . One

Armour, sent his now Majestie, Charles the second, by the great Mogull, consisting of backe, breast, Baces, headpeece, vizor, and peeces of the Greaves . . . . One

Trunckes wherein the said guilt Armour is laid . . 4

Great old Trunckes bound about with Iron, remaineing still at $\mathrm{M}^{\mathrm{r}}$. Anneslyes house

Great Leaden Cisterne, formerly brought from Greenwich, and now remaineing at the house where $\mathrm{M}^{\mathrm{r}}$. Anneslye dwellt in the Tower

. One

Greenwich. Wee doe find, aswell upon our owne view as upon the informacion of diverse officers of the Armoury, stoorekeepers and others, That, dureing the time of the late distraccions, The severall Armes, ammunicion, and Habiliments of Warre, formerly remaineing in the greene Gallery at Greenwich, were all taken and carryed away by sundry Souldiers, who left the doore open; That sundry of the said Armes were afterwards brought into the Tower of London by $\mathbf{M}^{\mathrm{r}}$. Anneslye, where they are still remaineing; That the Wainescot in the said Gallery is now all pull'd downe, and carryed away; and (as We are informed) was imployed in wainescotting the house in the Tower, where the said Mr. Anneslye lived; That a great part of the seeling is very much ruined, and the whole house much decayed: That all the severall Tooles and other utensills for makeing of Armour, formerly remaineing in the Master Armourers workehouse there, and at the Armourers Mill, were alsoe within the tyme of thee said distraccions taken and carryed away (saveing two old Trunckes bound about with Iron, which are still remaineing in the said workehouse, One old Glazeing wheele, still at the Mill, and one other glazeing wheele sold to a Cutler in shoe lane): That sundry of the said Tooles, and other utensills, have since byn converted and sold to private uses, by those who within the tyme of the said distraccions had the Comaund and care of the said armes and Tooles, both at Greenwich and at the Tower; That diverse of the said Tooles are still in other private mens hands, who pretend they bought them: That the great Anvile (called the great Beare) is now in the Custodie of $\mathrm{M}^{\mathrm{r}}$. Michaell Basten, locksmith at Whitehall, and the Anville knowne by the name of the little Beare, is in the custody of Thomas Cope, one of his Majesties Armourers; And one Combe stake in the Custody of Henry Keeme one other of his 
Majesties Armourers: And that the said Mill, formerly employed in grinding, glazeing and makeing cleane of Armes, is destroyed and converted to other uses by one $\mathbf{M}^{\mathrm{r}}$. Woodward, who claimes it by virtue of a Graunt from Kinge James (of blessed memorye) but the officers of the Armorye (for his Majesties use) have it now in their possession.

Memorandum. That the severall distinguishments of the Armors and Furnitures before mencioned, viz ${ }^{t}$ The first serviceable, The second defective, and to be repaired, The third unserviceable, in their owne kinds, yet may be employed for necessary uses, are soe reported by Richard Kinge and Thomas Cope, two of his Majesties Armorers at Greenwich, who were nominated and appointed in his Majesties Commission, under his signe Manual before recited, to be assistant in this Service: And we doe thinke the same to be by them faithfully and honestly soe distinguished.

Will. Legge, Master of his Majesties

Armories.
J. Robinson, Li: Ten: Toure. Jo. Wood. Barth. Beale.

The attempt to offer a detailed explanation of all the questions regarding armour and military costume,-suggested by the foregoing document, would be beyond the limits of our present purpose. The principal terms occurring in it have been satisfactorily interpreted by Sir Samuel Meyrick.

The chief divisions, under which ordinary defensive armour of the earlier half of the seventeenth century is here found to be classed, are, for Cavalry, Harquebuzeers', and Curasseers' armour; for infantry, corslets, and curats. This official return is perfectly in accordance with the statements of writers of the period, and the descriptions given by Markham, in his "Souldiers Accidence," printed 1645, with the schedule of prices of armour, established by a commission appointed by Charles I. in 1631, supply a complete explanation of the items here found, in regard to the equipment both of horse and foot $\mathrm{r}$. The harquebuzeers were light-armed horsemen, and their equipment was so derised as to give the greatest possible freedom of movement, requisite for the effective use of fire-arms; on which account they had head-pieces with great cheeks and a bar before the face, here designated as Dutchs. The armour of the heavy cavalry was of more complicated and ponderous description; the head-piece, or "casque" was close, the limbs were protected by vambraces, cuisses, and knee-caps, with the culet or guardereine.

r The prices were, for harquebuzecıs' armour, f1 $12 \mathrm{~s}$; ; cuirassiers', 2410 s. ; corslet for a foot soldier, $£ 12 \mathrm{~s}$. Crit. Enqu., vol. iii. p. 87.

- The harquebus was more usually the weapon of infantry, but horse-arquebusiers were employed in Germany as early as the fifteenth century, and also in the armies of Francis I. See Sir Samuel Meyrick's dissertation on the introduction and use of this fire-arm, Archrologia, vol, xxii. p. 63. A good representation of a mounted harquebuzeer is given in Capt. Cruso's Instructions for Cavalry, 1632. 
The armourers of our own country, we may here observe, were unable to provide the requisite supplies of military equipments, and the special commission for their encouragement, nominated by Charles I. as above cited, recites the inconvenience arising from the necessity of seeking for provision of arms from foreign parts, as heretofore accustomed. It is curious to notice the various defences of foreign fabrication, enumerated in the survey. The Spanish morions might have been preserved from the wreck of the Armada, and it is possible that the Flemish pouldrons and gauntlets had been part of the equipment of forces raised in the Netherlands, on that memorable occasion. We find also Danish foot-armour, Dutch armour and head-pieces, possibly part of stores purchased by Henrietta Maria in Holland, with the price of the crown jewels, in the disastrous position of affairs, in 1642. The custom-house rates, however, shew that the importation of armour must have been considerable at various times. Thus, according to the act 1 Mary, the duties on Almain rivets were rated at $6 \mathrm{~s} .8 \mathrm{~d}$. the harness, corslet harness complete, $20 \mathrm{~s}$. a piece (reduced in the rates 2 James I. to $12 \mathrm{~s}$. $4 \mathrm{~d}$.), harness, called dimilances, $26 \mathrm{~s}$. 8d., brigandines, 13s. 4 d., shirts of mail, $26 \mathrm{~s}$. $8 \mathrm{~d}$., and every description of offensive weapons, hand-guns, dagges and daggers, rapiers, halberts and partesans, flaskets for powder, steel saddles, morions and sallats, are enumerated in these curious official rates. Amongst foreign stores, the survey describes about 300 suits for infantry, as "armour of Toyras provision," with headpieces mostly made in England, to be used with them. Sir Samuel Meyrick supposed these to have been provided by the city of Tours, but he has stated no ground for the conjecture, nor the occasion on which it is probable that Touraine might have furnished any such supply. There is moreover no evidence that the name of that city was ever written Toyras. It may, however, be the name of some place in the Low Countries, or elsewhere, where armour was fabricated, or possibly the name of an armourer, noted at that period. A large number of these suits still remain, stamped upon the breast with the letters TorRAst, and we are in-
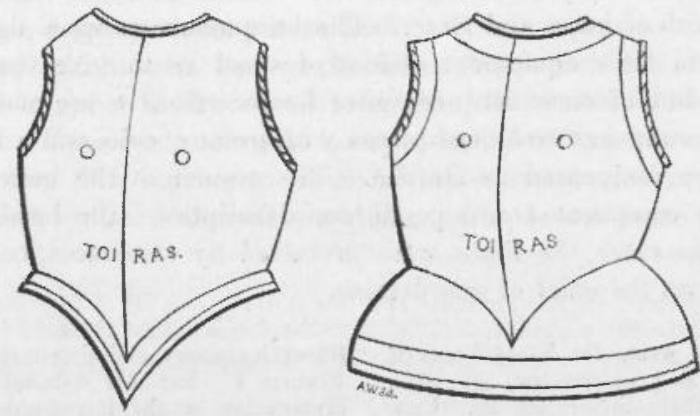

debted to the kindness of Mr. Hewitt for enabling us to give a repre-

' In one instance, apparently by accident, the letters being punched separately, ronas. 
sentation, sufficing to shew their fashion, and their date. In default of any conclusive evidence, it may be suggested that these had formed part of the equipment of infantry serving under the gallant Marechal de Toiras, and it seems not improbable, that they might have been supplied by the French general to assist Charles $I$. in the equipment of the expedition in aid of Lewis XIII. against the Hugonots in La Rochelle, in $1625^{4}$. Charles found himself at that time under the greatest difficulties, in his endeavours to fulfil the promises made by James I. to the court of France; he was burdened with debt, unable to obtain supplies from parliament, and compelled to borrow from his subjects for the outfit of that unpopular enterprise. If this explanation of the "Toyras provision" can be received as probable, these suits may present to the visitor of the Tower no uninteresting memorial of the vacillating policy of the times of Charles I. and of the expedients to which he was constantly reduced.

Various terms occur in this official return of William Legge, which might claim detailed notice, had not these observations already been extended too far. There is, however, one noticed already in the Journal $\mathbf{x}$, to which we must here take occasion again to advert. The explanation of the word mainefaire, adopted by Mr. Douce and Sir S. Meyrick, seems to have been first received as synonymous with crinet, or criniere, by Grose, who remarks, in his Treatise on Armour, that "the criniere or manefaire consisted of a number of small plates, generally about twelve, hooked together, and to the chafron, so as to be moveable: their use was to guard the neck of a horse," \&c. This interpretation seems to have been somewhat hastily drawn from a supposed allusion to the horse's mane; but the portion of horse-armour destined for that purpose is here distinctly designated by the term "crinet for the necke." The earliest mention of "manus ferrea," hitherto noticed, is in a document relating to deliveries and supplies of arms and armour by John de Flete, keeper of the jewels and military stores in the Tower, 13 Edw. III. The suggestion, previously offered in the Journal, appears to be confirmed by some descriptions of suits, omitted in Mr. Bray's copy of the returns of 1660 , and now first printed. Thus we find one described as tilt armour, cap-a-pie, wanting only gauntlets and mainefaire, and another small armour with pass guard, mainefaire and gauntlets, all mention of horse-armour being here omitted. It would thus appear that it was a piece of armour, repeatedly mentioned, as by Hall the chronicler, before cited, in connexion with gauntlets, and of which one alone was required. .It seems therefore, highly probable that

"We are indebted to the kindness of Mr. Holmes for this suggestion. The marquis de Toiras took an active part in the affairs of this period, and was successful in the capture of the Isle de Rhè, in 1625 , whilst the combined fleets of France, Holland, and England were under the command of the duke de Montmorency. Toiras is better known perhaps as the skilful opponent of Buckingham in the ill-fated expedition of 1627 , in favour of the Hugonots, in La Rochelle. It is possible that these suits may have been taken by the English on some other occasion, such as the capture of the French fleet by Blake, in 1655 .

$x$ See p. 231 of this volume. 
the mainefaire ("mano di ferro") was the defence for the left arm and wrist, of which many excellent examples may be seen in the Tower and at Goodrich Court. Its form and use, either with a gard-de-bras, or united to a rerebrace with a peculiar wing-shaped elbow-guard, are admirably shewn in Skelton's Illustrations, plates viii. and ix. In the former case this "long bridle-arm gauntlet," or "fixed gauntlet" as it is designated by Sir Samuel, is worn over the ordinary gauntlet, and attached to it by a screw and nut. It was used, as Sir Samuel remarks, in the tournament only, therefore the mention of one mainefaire with a pair of gauntlets, as part of a complete suit, is perfectly consistent with this explanation of the term ${ }^{y}$. The gantelet-d-coude, used in later times by the carabineers, is distinct, but it served in like manner for the bridle $\operatorname{arm}^{\mathrm{z}}$.

The description of head-piece termed "burgonet with a buffe or chin piece" is twice mentioned in the survey; rarious definitions have been given of the head-piece, supposed to have been of Burgundian origin, but the word "buffe" does not appear to have been noticed by any writer on military costume. It is of Italian derivation, as given by Florio, "buffa, the buffie or breathing hole of a head-piece," and Howell, in his useful Nomenclature, renders "the viser of a helmet, la buffa, baviera, la ventaglia." The name had doubtless been imported from Italy with the skilful productions of the Milanese armourers, long in high estimation ${ }^{2}$.

A. W.

${ }^{y}$ Compare the left gauntlet of the suit in the Madrid Armory, assigned by popular tradition to Boabdil. Jubinal, Armeria Real. See also the representation of a suit in the Tower, formerly attributed to Edward III. Grose, pl. 25, and Hewitt's Tower Armories, p. 13.

2 There are several in the Tower. Grose, pl. 26 ; Skelton, Illustr., pl. xl.

a Sir John Smithe, in his Instructions Militarie, 1595 , says of light horse, called Stradiots, "I would wish them all to bee armed with good burgonets and buffes, with collars, with cuirasses, with backs, and with long cuisses," \&c., p. 199. 